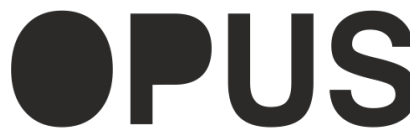

Uluslararası Toplum Araştırmaları Dergisi International Journal of Society Researches
E-ISSN : 2528-9535

Yll Year: 11

Cilt Volume: 18

Sayı Issue :Yönetim ve Organizasyon Özel Sayısı

Temmuz July 2021

Makalenin Geliş Tarihi Received Date: 12/03/2021

Makalenin Kabul Tarihi Accepted Date: 28/04/2021

\title{
Çalışma Hayatında Geleceğin İnsan Kaynağı: Alfa Kuşağ1
}

DOI: 10.26466/opus.895924

\author{
$*$ \\ Zümrüt Hatun Demirel* \\ * Dr. Öğr. Üyesi, Ankara Yıldırım Beyazıt Üniversitesi, Ankara/Türkiye \\ E-Posta: zumruthatun@gmail.com ORCID: 0000-0003-0300-6988
}

\section{Öz}

İşletmelerde insan kaynağı farklı kuşaklardan oluşmaktadır. Günümüzde ortalama dört kuşak yani Baby Boomers, X, Y ve Z kuşakları aynı iş yerinde çalışmaktadır. Bir de bu kuşaklardan önce yaşamış ilk kuşak olan Sessiz kuşak vardır. Sessiz kuşak yaşları itibari ile artık çalışma hayatında yer almamaktadır. İşyerlerinde farklı kuşakların çalışanlarını cezbedici ve tatmin edici ortamlar oluşturmak gün geçtikçe zorlaşmaktadır. İlgili yazın incelendiğinde çalışma hayatında mevcut bulunan kuşaklar; özellikle $X, Y$ ve Z kuşakları yer almaktadır. Fakat henüz çalışma hayatına girmemiş bir kuşak olan Alfa kuşă̆g hakkında çok fazla çalışma bulunmamaktadır. Bu araştırmanın amacı, çalışma hayatında hâlihazırda yer alan kuşaklar hakkında bilgi vererek gelecekte çalışma hayatında yer alacak olan Alfa kuşă̆ı hakkında bir ön görü sunmaktır. Alan yazında yer alan kuşak kavramı ile ilgili araştırmalar incelendiğinde ağırlıklı olarak Alfa kuşağından önceki kuşaklar araştırıldığı görülmüştür. Özellikle ülkemizde Alfa kuşă̆ hakkında bilgi vererek gelecekte çalışma hayatındaki etkilerini inceleyen bir çalışmaya rastlanmaması bu araştırmanın önemini ortaya koymaktadır. Ayrıca bu çalışma hem araştırmacılar hem de uygulayıcılar için önemli tespitleri içermektedir.

Anahtar Kelimeler: Çalışma Hayatı, İnsan Kaynağı, Kuşak Kavramı, Alfa Kuşağı. 


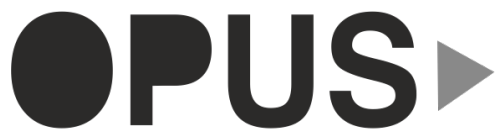

Uluslararası Toplum Araştırmaları Dergisi International Journal of Society Researches
E-ISSN : 2528-9535

YIl Year: 11

Cilt Volume: 18

Sayı Issue :Yönetim ve Organizasyon Özel Sayısı

Temmuz July 2021

Makalenin Geliş Tarihi Received Date: 12/03/2021

Makalenin Kabul Tarihi Accepted Date: 28/04/2021

\title{
Human Resource of the Future in Working Life: The Alpha Generation
}

\begin{abstract}
Human resources in businesses consist of different generations. Today, an average of four generations of Baby Boomers, X, Y and Z generations, work in the same workplace. There is also the Silent generation, which is the first generation that lived before these generations. The silent generation is no longer involved in working life as of their age. It is getting harder day by day to create attractive and satisfying environments for employees of different generations in workplaces. When the related literature is examined, there are the generations that are present in the working life, especially the $X, Y$ and $Z$ generations. However, there are not many studies on the Alpha generation, which is a generation that has not yet entered the business life. The aim of this research is to provide information about the generations currently in business life and to provide a foresight about the Alpha generation that will take place in business life in the future. When the studies on the concept of generation in the literature are examined it is seen that the generations before the Alpha generation are mainly investigated. Especially in our country, the fact that there is no study that examines the effects of the Alpha generation on the future work life by providing information about the future reveals the importance of this research. In addition, this study contains important findings for both researchers and practitioners.
\end{abstract}

Keywords: Working Life, Human Resources, Generation Concept, Alpha Generation 


\section{Giriş}

Toplumun ihtiyaçları teknolojik, bilimsel, kültürel ve ekonomik olarak değişmekte ve farklı dönemlerde yaşayan kişiler arasında farklı algılar ve davranışlar ortaya çıkmaktadır. Bu algı ve davranışlardaki farklılıklar "kuşak" kavramı ile açılanabilmektedir. Kuşak, benzer doğum yılları ve deneyimleri olan, düşünceleri, tutumları, değerleri, inançları ve davranışları çeşitli faktörlerden etkilenen ve sırayla bu faktörleri etkileyen bir grup bireyi ifade eden bir kavramdır (Kupperschmidt, 2000, s.67). Kuşak, toplumu oluşturan alt grupları tanımlamak için kullanılan popüler bir terminolojidir. Psikoloji, sosyoloji, yönetim, pazarlama ve kitle iletişimi gibi farklı araştırma alanlarında geniş bir uygulama alanına sahiptir.

Devletlerin politikaları gereği emeklilik yaşının yükseltilmesi ile artık herhangi bir organizasyonda, insan kaynağı farklı kuşaklardan oluşmaktadır. Çalışanların kuşak faktörü, işe bağlılıklarını, kariyer gelişimlerini ve ekip çalışmasını etkilemektedir (Pathirage ve Weerasinghe, 2020, s.2). Yirmi yıl önce, dünya genelinde çalışanlar en geç 60'larında emekli olmaktaydı. Ancak son yıllarda başta emeklilik yaşının devlet tarafından yükseltilmesi, sağlıklı yaşam süresinin artması veya 2008 ekonomik çöküşünün neden olduğu mali kayıplarını telafi etme ihtiyacıyla emekliliği hak ettiği halde aktif olarak çalışmaya devam eden iş görenler genç kuşak iş görenlerle aynı ortamda çalışmaktadır (Jiří, 2016, s. 106). Yiğit ve Aksay (2015)'a göre farklı yaş gruplarına mensup bireylerin farklı deneyimleri, farklı görüşleri, farklı alışkanlıkları ve farklı çalışma tarzları bulunmaktadır (Yiğit ve Aksay, 2015, s.105). Kuşaklar arasında işle ilgili farklı davranışlar tespit edilebilmekte ve bu farklı davranışlar, bir örgütün üretkenliğini etkileyerek doğrudan ve dolaylı olarak birçok çatışmaya yol açmaktadır (McGuire, Todnem ve Hutchings, 2007, s. 593).

Günümüzde çok kuşaklı bir işgücünü yönetmek, temelde kuşakların işle ilgili farklı davranış sergilemeleri nedeniyle gün geçtikçe zor bir hal almaktadır. Farklı kuşakların aynı iş ortamında çalışmalarında yaşanan sıkıntıların büyük bir bölümü kuşaklararası iletişim, alg1 ve yöntem bak1mindan farklılıklardan kaynaklanmaktadır (Latif ve Serbest, 2014, s.135). Oysaki insan kaynağı bir işletmenin başarılı bir şekilde faaliyetlerini sürdürebilmesi için en az finansal ve fiziksel kaynakları kadar gerekli olan bir kaynaktır (Erdoğdu, 2013, s.5). İşletmelerin üretim yapabilmesi için birçok 
üretim faktörüne ihtiyaçları vardır. İster mal ister hizmet üretsin bütün işletmeler için insan kaynağ 1 stratejik bir öneme sahiptir. İnsan kaynağ1 ikamesi çok zor temin edilen bir üretim faktörüdür (Turan, 2008, s.13). İşletmeler üretimi gerçekleştirebilmek için başka bir ifade ile üretim faktörlerini üretime yönlendirebilmek için insan kaynağının zihinsel ve bedensel gücüne ihtiyaç duymaktadır (Düren, 2000, s.97). Dahası işletmeler gerek ulusal gerekse uluslararası piyasalardaki yoğun rekabet ortamlarında varlıklarını sürdürebilmek ve başarı elde edebilmek için işletmeyi diğer işletmeler arasında farklılaştıracak, taklit edilmesi zor olan temel yeteneğe ihtiyaç duyarlar. İşletmeler kendilerine değer kazandıran temel yeteneği insan kaynağ1 sayesinde oluştururlar (Seyyar ve Öz, 2007, s.165).

Her neslin değerlere, inançlara ve davranışlara dayanan kendine özgü bir yapısı vardır ve bu kuşaksal benzersizlik, bireylerin işteki performansını büyük ölçüde etkiler. Bir organizasyonda veya işyerinde farklı kuşaklara sahip olmak faydalıdır. Çünkü farklı kuşakların farklı yetenek ve beceri çeşitliliği vardır (Hansen ve Leuty, 2012, s.35). Her bir farklılık işletmeye farklı bir renk katabilir. Ancak yine de farklı kuşaklardan oluşan çalışanları motive etmek yaşları gereği farklılaşan beklentilerini karşılamak yöneticiler ve işletme sahipleri açısından zor bir durumdur.

Çalışma hayatında şimdiye kadar yer alan diğer kuşaklar hakkında az çok bilgi sahibi olan araştırmacılar ve iş hayatı mensupları için geleceğin insan kaynağı olacak olan Alfa kuşağı ile ilgili yeterli bilgi bulunmamaktadır. Alfa kuşağı 2010 yılı sonrasında doğan bireyleri kapsamaktadır (McCrindle ve Wolfinger, 2010, s.10). 2021 yılı itibari ile en yaşlısı 11 yaşında olan bu kuşak en geç 10 yıl sonra iş hayatında yerlerini almaya başlayacaklardır. Bu durum Alfa kuşağı hakkında bilgi sahibi olmanın önemini gün geçtikçe artırmaktadır.

Bu çalışmada önce çalışma hayatında hâlihazırda bulunan kuşakların genel ve karakteristik özellikleri ile çalışma hayatında sergilemiş oldukları davranışların açıklanması, geleceğin insan kaynağı olacak olan Alfa kuşağı tanımlanarak karakteristik özellikleri ve iş hayatında beklenen davranışlarının açıklanması amaçlanmaktadır.

$\mathrm{Bu}$ ana amaçtan yola çıkarak ilgili konuda literatürde yer alan ulusal ve uluslararası çalışmalar incelendikten sonra çalışmada temel olan aşağ1daki araştırma soruları geliştirilmiştir: 
- Alfa kuşağından önceki kuşakların genel ve karakteristik özellikleri nelerdir?

- Alfa kuşağından önceki kuşakların çalışma hayatında sergilemiş oldukları davranışlar nelerdir?

- Alfa kuşağının genel ve karakteristik özellikleri nelerdir?

- Çalışma hayatında Alfa kuşağının hangi davranışları sergilemesi öngörülmektedir?

\section{Kuşak Kavramı}

"Kuşak" kavramı, "jenerasyon" ve "nesil" kelimeleri ile eş anlamlı kullanılan bir kavramdır. Türk Dil Kurumu, kuşak kavramını "aynı yıllarda doğmuş, aynı yaşta aynı şartları paylaşan ve bu nedenle benzer kaderi, sorunları paylaşan ve benzer görevlerden sorumlu insan toplulukları" olarak tanımlamaktadır (www.sozluk.gov.tr/.). Demografik açıdan kuşak milletlerin doğum ylllarındaki bir resmini temsil eder (McCrindle, 2014, s.35). Genel olarak kuşak yaşa göre kategorize edilir. Kuşağın göstergesi olarak yaş, karmaşık toplumu anlamayı kolaylaştırmanın bir yoludur (Rogler, 2002, s.1015). Ancak kuşakları yalnızca doğdukları yıllar bakımından sınıflandırmak doğru olmayacaktır. Kuşakları oluşturan kişilerin düşüncelerinin, duygularının ve tecrübelerinin de bilinmesi gerekmektedir (Taş, Demirdöğmez ve Küçükoğlu, 2017, s.1035). Ayrıca yaşa ek olarak sosyal yapısal unsurlar, sosyal hareketlilik, etnik heterojenlik, bölgesel çeşitlilik ve kitle iletişim araçlarıyla beslenen kitle kültürü de kuşakları sınıflandırmak için kullanılır. Bu anlamda, kuşak etiketleri, çağdaş toplumun bilişsel anlamını oluşturmanın bir yolunu temsil eder (Rogler, 2002, s.1015).

Sosyolojik açıdan, kuşaklar farklı bakış açılarından incelenmiştir. Kertzer (1983, s.126)'e göre kuşak, birbiriyle akraba olarak karşıllılı özellikler taşıyan bir grup insandır. Kuşak; dünyada yaşanan olaylar, doğal afetler, politika, ekonomik koşullar ve popüler kültür gibi ortak yaşam deneyimlerini paylaşan bir grup insanı ifade eder (Hansen ve Leuty, 2012, s.36). Kuşaklar, onları iç gruba bağlayan ve onları dış gruptan ayıran farklı sembollere ve ayırt edici özelliklere sahiptir. Her kuşağın üyeleri, karmaşık bir algılar, yargılar ve duygular ağıyla birbirine bağlıdır (Rogler, 2002, s.1014). 
Mannheim (1952) 'a göre aynı kuşağın üyeleri, aynı yıllarda olan olayları aynı şekilde yaşamışlardır dolayısı ile ortak bir kültürel alanı paylaşırlar (akt. Eyerman ve Turner, 1998, s.92). Kuşak üyeleri; birbirlerinin düşüncelerini, tutumlarını, değerlerini, inançlarını ve davranışlarını etkileyen ortak bilgi ve deneyimlere sahip olan, eşzamanlı olarak doğan ve yaşayan bir grup bireydir (Johnson ve Johnson, 2010, s.67). Kuşaklar düşüncelerinde, değerlerinde, davranışlarında, inançlarında, tutumlarında ve deneyimlerinde ortaktırlar ve kuşakların bu ortak faktörleri yaşadıkları dönemde o toplum için kültürü, ekonomiyi ve siyasi görüşleri oluşturur (Guilloti-Soulez ve Soulez, 2014, s.320). Kuşaklar içinde bulundukları kültürün içinde bulunan standartlarına göre şekil almaktadır. Her kuşak gelişme imkânı bulduğu toplumun kültüründen olumlu ya da olumsuz etkilendiği gibi onu etkileme özelliğine de sahiptir. Bu bakımdan kuşaklarla toplumsal kültür arasında karşlıklı bir iletişim mekanizmasının bulunduğunu söylemek mümkündür (Altuntuğ, 2012, s. 204).

Her kuşağın hayata bakışı, iş yaşamından beklentisi, iletişim şekilleri, değer yargıları, zayıf ve güçlü yönleri farklılık göstermektedir. Kuşaklar yaşadıkları dönemlerdeki politik, siyasi, ekonomik ve çevresel değişimlerden etkilenmektedir (Kırık ve Köyüstü, 2018, s.1498). Kuşakları oluşturan bireyler yetişkin olana kadar, karşılaştıkları tarihsel olaylardan büyük ölçüde etkilenmektedir. Bu paylaşılan olayların gücü ve etkisinin bir sonucu olarak, her kuşak benzersiz bir inanç, tutum ve davranış yapısı oluşturmaktadır. Otorite ve kuruluşlara karşı sahip olduğu duyguları şekillendiren benzersiz bir kimlik oluşturmaktadır (Giancola, 2006, s.33).

\section{Kuşak Çeşitleri}

Kuşak kavramı "25-30 yıllık süreleri kapsayan belli bir bölgede ve o bölgenin kültüründen etkilenerek yetişen insanları" ifade etmektedir (Chen, 2010, s.132). Biyoloji temelli bu tanımda aslında ebeveyn ve çocuğu (veya çocukları) arasındaki ortalama 23-30 yılı kapsayan zaman aralığı hesaplanmıştır (Cannemo, 2005, s.62). Fakat bazı kaynaklarda günümüzde çocuk sahibi olma yaşının eskiye nazaran daha geç olması sebebiyle ebeveyn-çocuk yaş farkının 40 yıla kadar çıktığı kuşak aralığının 40 yıla çıkarılabileceği savunulmuştur (Eyerman ve Turner, 1998; Mort, 1996;). Farklı 
kaynaklarda ise tam tersi, teknolojinin hızlı gelişmesi, toplumun değerlerindeki ve çalışma koşullarındaki değişikliklerin hızlanması gibi sebeplerle 20-30 yıllık zaman diliminin bir kuşağın özelliklerini koruyabilmesi için çok uzun bir zaman olduğu belirtilmektedir (McCrindle ve Wolfinger, 2010; Reeves ve Oh, 2008). Bu gibi sebeplerle kuşakları sınıflandırırken yalnızca insanların doğdukları tarihleri göz önüne almak doğru olmayacaktır. Kuşaklar sınıflandırılırken tarihi ve toplumu etkileyen olaylar, durumlar ve şartların da incelenmesi gerekmektedir (Zemke, Raines ve Filipczak 2013, s.71).

Kuşak kavramı ile ilgili yazın incelendiğinde altı farklı kuşaktan bahsedilmektedir (Howe ve Strauss, 2005; Lanchester ve Stillman, 2002; Martin ve Tulgan, 2003). Bu kuşaklar: Sessiz Kuşak, Bebek Patlaması Kuşağı, X Kuşağı, Y Kuşağı, Z Kuşağı ve Alfa kuşağıdır (Cook, 2015; Hammill, 2005; Wasserman, 2007). Günümüzde aktif iş yaşamında rol alan bebek patlaması kuşağı ile X, Y, Z kuşaklarıdır.

Sessiz Kuşak (The Silent Generation): Sessiz kuşak çağımızın en eski kuşağıdır, 1925-1945 yılları arasında doğmuşlardır ve çoğu emekli olmuştur. Sessiz kuşak geleneksel kuşak olarak da bilinir. Sessiz kuşak adından ilk kez 1951 Time dergisindeki bir makalede bahsedilmiştir. Bu kuşağa içine kapanık, temkinli ve sessiz özellikler yansıtması sebebiyle bu isim verilmiştir (Strauss and Howe, 1991, s.198). Bu kuşak toplumlarının altyapıs1nın, ekonomisinin, kurumlarının ve örgütlerinin kurucuları olmuşlardır. Tarım ekonomisinden modern, sanayileşmiş bir ekonomiye geçişte önemli rol oynamışlardır (Stevenson, 2009, s.55). Sessiz kuşak, en erken yaşta evlenip çocuk sahibi olan kuşaktır. Aile kavramı onlar için son derece önemlidir (Hansen ve Leuty, 2012: 36). Sessiz kuşak 2020 yılı itibari ile ülkemiz nüfusunun \% 5'ini oluşturmaktadırlar (www.nufusu.com.).

1929 Büyük Ekonomik Buhran ve II. Dünya Savaşı sırasında büyüyen bu nesil, zor günler geçirmiştir. Savaş döneminden oldukça etkilenen bu kuşağın temel değerleri otoriteye karşı saygı, iş ahlakı ve dürüstlüktür (Kyles, 2005, s.54). Bu bireyler çalıştıkları örgütlere karşı son derece sadıktırlar. Genellikle bir örgütte uzun süre çalışmayı planlayan kişiler olarak tanımlanmaktadırlar (Lancherter ve Stillman, 2002, s.27). Sessiz kuşak çalışmayı bir görev ya da zorunluluk olarak görmektedir. İyi yaptıkları bir 
iş için sözlü veya yazılı olarak takdir edilmeleri onları motive etmeye yetmektedir (Kyles, 2005, s.54).

Bütün dünyayı etkileyen Büyük Ekonomik Buhran döneminde edindikleri zorlu deneyimler onları yıllar süren tasarrufa yöneltmiştir (Kupperschmidt, 2000, s.68). Otorite figürlerine sayg1; işverene, sektöre, markaya ve millete bağl1lık egemen olan toplumsal değerleridir. Bu kuşağın üyeleri düzen ve dengeyi tercih eden, geleneklerine bağlı, liderlerinden sürekli direktifler bekleyen, karar verme konusunda sıkıntı yaşayan, teknolojiye kolay uyum sağlayamayan kişilerdir (Bilgin, 2010).

Bebek Patlaması Kuşağı (Baby Boomers): 1946-1964 yılları arasında doğan kuşak bebek patlaması kuşağı olarak bilinmektedir. Kuşak sınıflandırmasına göre ikinci kuşaktır (Holton ve Fraser, 2015, s.3). 1946-1955 yılları arasında doğanlara "öncü boomers" 1956-1964 yılları arasında doğanlara ise "geç boomers" adı verilmiştir (Wiedmer, 2016, s.52). II. Dünya savaşının son bulması ile yaşanan refah ortamı ile pek çok ülkede özellikle Avrupa ve Amerika' da doğum oranlarının hızla artması sonucu bu kuşak Bebek Patlaması Kuşağı adını almıştır ve en kalabalık kuşak olarak kabul edilmiştir (Johnson ve Johnson, 2021, s.21; Williams ve Page, 2011, s.5). BB (Baby Boomers) kuşağı aynı evin içinde önce çocuklarının daha sonra da ebeveynleri yaşlanınca da onların bakımlarını üstlenmişlerdir. Bu sebeple bebek patlaması kuşağı 'sandviç kuşak' olarak da anılmaktadır (Kuyucu, 2014, s.57). 2020 yılı itibari ile BB kuşağı Türkiye nüfusunun \% 21'ini oluşturmaktadirlar (www.nufusu.com.).

BB kuşağ 1 üniversitelerin az sayıda olduğu dönemde üniversite eğitimi almanın zor fakat itibarlı bir durum olduğunu fark etmiştir (Oblinger, 2003, s.38). Aslında BB kuşağının 'disiplinli' bir eğitim hayatları olmuş ve bu disiplin iş hayatlarına da yansımıştır (Adıgüzel, Batur, ve Ekşili, 2014, s.166). Bu kuşağın üyeleri çalışma hayatında disiplinli, başarılı olmak için 'fedakârlık' gibi bedellerin ödenmesi gerektiğine inanan, çalışkan, işbirliğini seven, kariyerlerine değer veren, işverenlerine sadık ve aynı işyerinde uzun süre çalışan kişilerdir. Dahası bu kişiler hayatlarını işleri ile anlamlandıran işkolikler olarak görülmektedirler (Tolbiz, 2018, s.24).

BB kuşağı çevreye ve toplumsal olaylara karşı duyarlı, kadın erkek eşitliğine inanan, ırk ayrımcılığına karşı mücadele eden bir kuşaktır. Bu kuşak 
gençlik yıllarında "68 Hareketi" adı verilen başkaldırı hareketinin temellerini oluşturmuşlardır (Crampton ve Hodge, 2006, s.20). Ayrıca bu kuşağın mensupları, insanoğlunun ilk uzay seyahati (1957), ABD Başkanı Kennedy suikastı (1963), II. Dünya Savaşı sonrası ABD-SSCB arasındaki soğuk savaş, ABD'nin Vietnam savaşı (1955) gibi tarihteki önemli olaylara tanıklık etmişlerdir (Ting, Lim, Cyril de Run, Koh, ve Sahdan, M 2018, s.111).

X Kuşağı (Generation X): Kuşak sinıflamasının üçüncüsü olan X kuşağ1 1965-1980 yılları arasında doğan kişileri kapsamaktadır (Altuntuğ, 2012; Kaifi, Nafei, Khanfar ve Kaifi, 2012). Bu yıllarda yaşanan kadın haklarındaki gelişmeler: doğum kontrol yöntemlerinin yaygınlaşması ve kürtajın yasal bir duruma gelmesi gibi sebeplerle doğum oranlarının azalması ile birlikte $X$ kuşağ 1 kuşaklar sınıflandırılmasındaki en az sayıda nüfusa sahip kuşaktır (Keengwe ve Agamba, 2014, s.274). X kuşağı 2020 yılı itibari ile ülkemiz nüfusunun \% 22'sini oluşturmaktadırlar (www.nufusu.com.).

$X$ kuşağı büyürken; petrol ve enerji krizleri, medyanın gelişimi ve yükselmesi, toplumlarda suç ve boşanma oranlarında artış, AIDS hastalığının yayılması, sağ-sol çatışmaları, siyasi darbeler gibi birçok gelişmeye tanıklık etmişlerdir. Bu gelişmelerin; dönemi ekonomik, siyasi ve kültürel aç1lardan etkilemesinden dolayı bu kuşağa “Gölge Kuşak" veya "Kayıp Kuşak" da denilmektedir (Baker, 2018; Losyk, 1997).

Özellikle kadınlar bu dönemde çalışma hayatına ağırlıklı olarak katılmaya başlamıştır. Dolayısı ile bu kuşak her iki ebeveynin de çoğunlukla ev dışında çalıştığı, ebeveynler işteyken her gün saatlerce kendilerine bakmak zorunda kalan ilk kuşaktır (Strauss ve Howe, 1991, s.200). Bazı araştırmacılara göre yalnız büyümeleri bu bireylerin bağımsızlık, uyum sağlama ve dayanıklılık becerilerini geliştirmiştir (Losyk, 1997; Scheef ve Thiefoldt, 2004). Ancak bazı araştırmacılara göre ise ebeveyn şefkatinden mahrum kalan bu çocuklarda yalnızlık, korku, kaygı, bunalım gibi psikolojik hallerin ortaya çıkması kaçınılmaz olmuştur. Hatta bu hallerin sigara, alkol, uyuşturucu kullanımının artmasına sebep olduğu iddia edilmektedir (Karp, Fuller ve Sirias, 2002; Toch ve Frady, 1984).

$\mathrm{X}$ kuşağ 1 işkolik anne-babalar tarafından yetiştirildiklerinden ve erken yaşlarda üzerlerinde ebeveyn otoritesi bulunmadığından çalışma hayatlarında yönetilmekten hoşlanmazlar yaratıcılıklarını kullanarak hedeflerine ulaşmayı tercih ederler (Buckley, Beu, Novicevic ve Sigerstad, 2001, s.81). 
Yalnız çalışırlar, iş odaklıdırlar, iş ve aile dengesine dikkat ederler (Latif ve Serbest, 2014, s.140). Yalnız büyümeleri sebebiyle aile kavramına değer veren, iş-aile taleplerini dengeleyen kişiler oldukları varsayılmaktadır (Losyk, 1997, s.40).

X kuşağı mensupları sosyal olaylara karşı duyarlı, otoriteye karşı saygılı ve işle ilgili yüksek motivasyona sahiptirler. İşyerlerinde onları yaptıkları işle ilgili olumlu veya olumsuz geribildirimler, zorluklar ve gelişim fırsatları motive eder (Quinn, 2010, s.32). Öte yandan duruma göre bağl1lık duygusu geliştiren, her zaman için daha iyi kariyer fırsatları arayan bir kuşaktır. Örgütlerine olmasa da işlerine olan bağlılıkları oldukça yüksektir (Alwin, 2002, s.42).

X kuşağı bilgi ve iletişim teknolojilerindeki hızlı değişimlerle karşı karşıya kalmışlardır. Doğduklarında merdaneli çamaşır makinesi, pikap, transistörlü radyo bulunan bu kuşağın üyeleri teknolojik alanda birçok gelişmeyi yaşamışlardır (Taş vd., 2017, s.1035). Bu dönemde ilk kişisel bilgisayar satışının yapılması ve bilgisayar sistemlerinin iş hayatına dâhil olması örgütlerde iş yapma şekillerinin değişmesine sebep olmuştur. X kuşağı iş hayatında bu değişimlere adapte olmaya çalışmıştır (Jorgensen, 2003, s.42). Aslında bu kuşak bir yandan aile kavramı ve otoriteye sayg1 gibi davranışlarla geleneksel dönem davranışları sergilerken bir yandan da teknolojik gelişmeler neticesinde modern dönem arasında sıkışmış bir kuşaktır.

Y Kuşağı (Generation Y): X kuşağından sonra gelen ve kuşak sınıflamasının dördüncüsü olan Y kuşağı 1981-1999 yılları arasında doğan bireylerden oluşmaktadır (Harber, 2011; Rainess, 2003). Y Kuşağına aynı zamanda Milenyum Kuşağ1 (Millennials), Gelecek Kuşak (Generation Next) ve Dijital Kuşak adları da verilmektedir (Andrea, Gabriella ve Timea, 2016; Holton ve Fraser, 2015; Tolbiz, 2018). Y kuşağ1 üyeleri 20. yy'da doğan son kuşaktır (Reisenwitz ve Iyer, 2009, s.92).

Bebek patlaması kuşağından sonra en yüksek nüfusa sahip kuşaktır (Kavalc1 ve Ünal, 2016, s.1037). Günümüz dünya nüfus oranına sahip en yüksek kuşaktır. Birleşmiş Milletler Nüfus Fonu (UNFPA) tarafından hazırlanan Dünya Nüfus Raporu 2020 (State of World Population 2020) verilerine göre 2020 yılı itibari ile dünya nüfusu 7,78 milyara ulaşmıştır. Dünyadaki bu nüfusun 1,8 milyarını Y kuşağ1 üyeleri oluşturmaktadır 
(www.turkey.unfpa.org). 2020 yılı itibari ile Türkiye nüfusunun \% 35'ini oluşturmaktadırlar (www.nufusu.com). Bu da pek çok Avrupa ülkesinin toplam nüfusundan fazlasına tekabül etmektedir (Çetin ve Karalar, 2016, s.160).

Tıpkı X kuşağında olduğu gibi $Y$ kuşağında bulunan bireylerin çoğunluğu çalışan anne-babalara sahiptirler. Ancak bu kuşağın ebeveynleri çocuklarının iyi koşullarda büyümesi, iyi eğitim alması ve en önemlisi de güvende olmaları konusunda son derece duyarlıdırlar (Kırık ve Köyüstü, 2018, s.1502). Hatta Y kuşağını yakından takip ederek yetiştiren, her zaman yanlarında olan özellikle çocuklarının karşılaştığı engelleri onlar adına ortadan kaldıran "Helikopter Ebeveynler" adı verilen anne-babalar tarafından büyütülmüşlerdir (Segrin, Woszidlo, Givertz, Dauer ve Murphy, 2012, s.238).

1980 sonrası yaşanan Büyük Teknoloji Devrimi sırasında büyüyen bu kuşak hayatları boyunca teknoloji olmayan bir dönemi görmemişlerdir (Tahmaz, 2019, s.211). Teknoloji hayatlarındaki birçok şeyin sembolüdür. Teknoloji konusunda X kuşağına kıyasla daha yetkindirler (Lower, 2008, s.80). Bu kuşak üyelerinin üçte ikisi beş yaşın altında bilgisayarla tanışmıştır. Akıllı telefonlar, dizüstü bilgisayarlar ve sosyal medya ile büyüyen ilk kuşaktır. İletişim kurarken daha çok çevirim içi teknolojiyi kullanırlar (Zemke vd., 2013: 120). Dijital teknoloji Y kuşağının davranışlarını büyük ölçüde etkilemiştir. Bu kuşağın özellikleri, değerleri ve beklentileri üzerinde dijital teknolojinin belirleyici bir etkisi bulunmaktadır (Greenfield, 2009, s.69).

Y kuşağının en önemli karakteristik özellikleri arasında bireysel, özgürlüklerine düşkün ve girişimci olmaları sayılabilir. Bir kısmı kendi işinin patronudur ve yüksek yaşam standartlarına sahiptir (Holton ve Fraser, 2015, s.5). Çalışmayı sevmeyen yaşamak için çalışmak zorunda olduklarına inanan bir kuşaktır. Bugünü yaşayan ve uzun süreli plan yapmayan bireylerdir (Çelik ve Gürcüoğlu, 2016, s.210). Kurallardan ve otoriteden hoşlanmayan, hızlı tüketen, tatminsiz davranan bu kuşağın bir diğer özelliği de özgüvenlerinin yüksek olmasıdır. İlgi odağı olmaktan çok hoşlanırlar. Beklentileri net, hedefleri yüksektir (Arslan ve Staub, 2015, s.7).

Y kuşağı temsilcileri çoklu görev üstlenebilirler, aynı anda birden fazla iş yapabilirler, adaptasyon kapasiteleri yüksektir (Yüksekbilgili, 2015, s.263). Diğer yandan mesleklerinden, işlerinden ve örgütlerinden kolayca 
sıkılıp bırakabilirler. Sadakat ve bağlılık duyguları zayıftır. İş etiğinden yoksundurlar (Andrea vd., 2016, s.96). Danışmanlık, bilişim ve finans alanlarında çalışmayı tercih ederler. Çalışacakları örgütün kimliğini, çok uluslu olmasını, kariyer ve eğitim imkânlarını göz önünde bulundururlar (Ayhün, 2013, s.97).

Z Kuşağı (Generation Z): Z kuşağı 21.yy'da doğan ilk kuşaktır ve kuşak sınıflandırmasının beşinci kuşağıdır. Bazı kaynaklara göre 2000-2020 yılları arasında (Levickaite, 2010; Malloy, 2012) doğanlar; bazı kaynaklara göre ise 1995-2010 tarihleri arasında (Bejtkovsky, 2016; Pathirage ve Weerasighe, 2020) doğanlar $Z$ kuşağına dâhil edilmiştir. 2000 yılı ve sonrasında doğan bu kuşağın $Z$ kuşağı olarak isimlendirilmesinin nedeni kuşak araştırmacısı ve sosyolog olan Strauss ve Howe'un (1991) Z kuşağını son kuşak olduğunu düşünmelerindendir. Aynı zamanda bu kuşak 'İnternet Kuşağı (IGEN)', 'Sıfır Kuşak (Gen Zero)', 'M Kuşağı (Mobile-Multitasking: birçok işi aynı anda yapma)', 'Kristal Kuşak' olarak da adlandırılmaktadır (Holton ve Fraser, 2015; Malloy, 2012; Prensky, 2001). 2020 yıl1 itibari ile 2000-2019 yılları arası doğumlular Türkiye nüfusunun \% 17'sini oluşturmaktadırlar (www.nufusu.com).

$Z$ kuşağını diğer kuşaklardan ayıran en önemli nokta dijital teknolojiyle doğup büyümeleridir (Beyaz, 2020, s.56). Aslında Z kuşağı ile Y kuşağı arasında yaşadıkları dönemin teknolojisi anlamında benzerlikler olsa da $Z$ kuşağını $Y$ kuşağından ayıran en önemli özellik $Z$ kuşağının daha farklı bir teknolojinin içine doğmasıdır. Z kuşağı, 90'lı yıllarda internetin yaşamımıza girmesi ile zamanla akıllı telefonlar ve sosyal medyanın var ettiği bir sanal dünyayla tanışmışlardır (Hariadi, Dewiyani, ve Pantjawati 2015, s.427). İletişimlerini ve arkadaşlık ilişkilerini yüz yüze, telefonla görüşme veya elektronik posta yerine sosyal medya aracılığı ile yürütmektedirler. İnternet ortamı olmadan hayatın ne demek olduğunu bilmemektedirler (Serinikli, 2019, s.184). Akıllı cihazları ileri beceri düzeyinde kullanmaktadırlar. Akıllı cihazlarla aynı anda müzik dinlerler, blog yazarlar, elektronik postalarını takip ederler, sosyal medya ağlarında dolaşarak mesajlaşırlar, film vs. izlerler (Nagy ve Kölcsey, 2017, s.109).

$\mathrm{Z}$ kuşağı hem gerçek hem de sanal dünyada çalışabilmektedir. Bu iki dünya arasında hızlı ve sürekli gezinti yapabilmektedirler (Mıstık, 2019, 
s.78). İhtiyaç duydukları bir veriye kolayca ulaşabilir ve o veriyi paylaşabilirler. Bilgiye ulaşma kapasiteleri yüksektir. Bilgiyi sadece tüketmezler aynı zamanda üretip kontrol edebilme yetisine sahiptirler (Taş, vd., 2017, s.1036). Kuşaklar arasında el-göz-kulak uyumu ve motor becerileri en yüksek olan kuşaktır (Taş vd., 2017, s.1037). El-göz-kulak uyumu yüksek olmalarına karşın odaklanma süreleri diğer kuşaklarla kıyaslandığında oldukça kısadır (Altunbay ve Bıçak, 2018, s.133).

Alfa Kuşağı: Tanımı ve Karakteristik Özellikleri: Latin alfabesinin son harfi $\mathrm{Z}$ olsa da kuşak gelişimi bitmemektedir ve $\mathrm{Z}$ kuşağından sonra gelecek olan kuşağa verilecek isim merak edilmekteydi. Sosyal bilimcilerin $X$, $Y$ ve $Z$ kuşaklarının alfabetik teması üzerinde bir fikir birliği bulunmaktaydı. Z kuşağından sonra gelecek olan kuşak için mevcut olana geri dönmek yerine yepyeni bir nesil ve yüzyıl için yepyeni bir başlangıcı temsil etmesi gerektiğini düşündükleri için sosyologlar Yunan alfabesini etiketleme dizisi olarak kullanmaya karar vermişlerdir (McCrindle ve Fell, 2020, s.5). Avusturalyalı demografi uzmanı Mark McCrindle Z kuşağından sonra gelecek olan kuşağın ismi ile ilgili 2015 yılında Avustralya genelinde bir anket düzenlemiş ve Yunan alfabesinin de ilk harfi olan "ALFA" ismi en çok tercih edilen isim olmuştur. Dolayısı ile Z kuşağından sonra gelen kuşak 'Alfa' olarak isimlendirilmiştir (Nagy ve Kölcsey, 2017, s.110).

İnsanlığın dünyadaki son temsilcileri olan Alfa kuşağı 2010 yılı ve sonrasında doğanları kapsamaktadır. Bazı araştırmacılara göre 2010-2025 yıllar arasında doğanları Alfa kuşağı kapsamına almışlardır (Apaydın ve Kaya, 2020; Jha, 2020; McCrindle, 2007). Ancak Nagy ve Kölcsey (2017, s.112), Strauss ve Howe'un (1991) "bir kuşağın oluşması için 20 yıllık bir yaşam süresinin dolması gerektiği" ne atıfta bulunarak 2010-2030 y1lları arasında doğanların Alfa kuşağı olarak kabul edilebileceğini belirtmektedir.

Alfa kuşağına "dijital yerliler de denilmektedir. Bilgi teknolojileri ile ilgili gelişmiş bilgi ve becerilere sahiptirler. Bilgisayarların, video oyunlarının ve internetin yani dijital dünyanın anadilini çok iyi bilirler ve kendi içlerinde bu dili kullanırlar (Prensky, 2001, s.1) Alfa kuşağıyla ilgili söylenebilecek en önemli şey doğdukları dijital ortamdır. Teknoloji, ebeveynleri, eğitimcileri ve sosyal etkileşimler günlük hayatlarını etkileyen en önemli unsurlardır (Tootell, Freeman ve Freeman, 2014, s.82). 'Bağlantı' 
kavramı bu kuşak için hatta önceki kuşak olan Z kuşağından bile daha önemlidir (Riediling, 2007, s.182). Alfa kuşağının başlangıcı olarak kabul edilen 2010 yılından itibaren yalnızca internet vs. alanında değil bilimsel ve teknolojik anlamda pek çok gelişme yaşanmıştır. Tablo 1.1.'de 20102019 yılları arasında bilim ve teknolojide yaşanan gelişmeler kronolojik olarak yer almaktadır.

Tablo 1. 20102019 Yilları Arasında Bilim ve Teknolojideki Gelişmeler

\begin{tabular}{|c|c|}
\hline YILLAR & BİLİMSEL VE TEKNOLOJİK GELİŞMELER \\
\hline \multirow{3}{*}{2010} & Apple'ın ilk tablet modeli olan iPad'i piyasaya sürüldü. \\
\hline & Sosyal medya uygulaması olan Instagram faaliyete geçiridi. \\
\hline & $\begin{array}{l}\text { Block Chain (Blok Zinciri) kripto para birimi olarak Bitcoin'in yani dijital para- } \\
\text { nın çekirdek bileşeni olarak uygulamaya başlandı. }\end{array}$ \\
\hline \multirow[t]{4}{*}{2011} & $\begin{array}{l}\text { Sağlıktan eğitime, finanstan endüstriye birçok alanda yapay zekâ uygulamala- } \\
\text { rına başlandı. }\end{array}$ \\
\hline & Drone teknolojisi ilk kez askeri ve savunma amacı dışında kullanıldı. \\
\hline & Mars yüzeyine araştırma yapmak amacıyla ilk uzay aracı indirildi \\
\hline & 4. nesil kablosuz iletişim teknolojisi olan 4G kullanılmaya başlandı \\
\hline \multirow[t]{2}{*}{2012} & İlk sanal gerçeklik gözlüğü olan Oculus VR tanıtıldı \\
\hline & $\begin{array}{l}\text { Sosyal medya uygulaması olan Facebook'un aktif kullanıcı sayısı } 1 \text { milyara } \\
\text { ulaştı. }\end{array}$ \\
\hline \multirow[t]{2}{*}{2013} & Sentetik biyoloji çalışmaları ile laboratuvarda ilk sentetik organ üretildi \\
\hline & Kripto para birimlerinden biri olan Etherium piyasaya sürüldü. \\
\hline \multirow[t]{4}{*}{2014} & Microsoft Windows 10 işletim sistemini kullanıcıları ile buluşturdu. \\
\hline & Mars yüzeyinin altında su bulundu. \\
\hline & Insansı robotlar geliştirilmeye başlandı. \\
\hline & Elektrikli kaykaylar ilk kez piyasaya sürüldü. \\
\hline \multirow[t]{2}{*}{2015} & 3D yazıcıyı temel alan üretime başlandı. \\
\hline & İlk akıllı saat olan Apple Watch'ın ilk sürümü tanıtıldı \\
\hline \multirow[t]{4}{*}{2016} & Microsoft ilk artırılmış gerçeklik gözlügü olan HoloLens'i piyasaya sürdü. \\
\hline & İlk artırılmış gerçeklik oyunu olan PokemonGo mobil oyunu hayatımıza girdi. \\
\hline & Google yapay zekâlı asistanı Google Asistan kullanıcılarıyla buluştu. \\
\hline & 4.5G iletişim uygulaması kullanılmaya başlandı. \\
\hline 2017 & Sosyal medya uygulamalarından biri olan TicToc faaliyete geçirildi. \\
\hline 2018 & $\begin{array}{l}\text { Amazon ilk kasiyersiz alışveriş deneyimi Amazon Go ABD'de kullanıma su- } \\
\text { nuldu. }\end{array}$ \\
\hline 2019 & Çevirim içi yayın yapan dijital platformlar kuruldu \\
\hline
\end{tabular}

Kaynak:https://www.pcmag.com/feature/371755/the-most-iconic-tech-innovations-of-the-2010s; https://time.com/collection/best-inventions-2018/; https://time.com/collection/best-inventions-2019/ in-

ternet adreslerinden faydalanılarak tablo araştırmacı tarafindan hazırlanmıştır. 
Alfa kuşağının çalışma hayatındaki davranışları hakkında tahminde bulunabilmek için bütün Alfa'ların karakteristik özelliklerini yorumlamak gerekmektedir. Barkowitz 'in (2016) Alfa kuşağını gözlemleyerek ve aileleriyle görüşerek yapmış olduğu etnografik araştırma ve buna ek olarak Ramadlani ve Wibisono'nun $(2017$, s.5) araştırmaları sonucunda aşağıdaki Alfa kuşağına ait özellikler tespit edilmiştir;

- Paylaşımdan nefret ederler, her şeyin tek sahibi olmak isterler.

- Son derece hareketli ve aktiftirler. Ancak gürültü yapmazlar. Özellikle 0-6 aylık bebeklik dönemlerinde yapılan incelemelerde sessiz oldukları gözlenmiştir.

- Mahremiyet onlar için önemli değildir. Deneyimlerini dünyayla paylaşmaktan çekinmezler.

- Kurallardan hiç hoşlanmazlar. Hatta kural tanımazlar.

- Her türlü kısitlamadan ve alanlarında sinır bulunmasından hoşlanmazlar.

- Sağlıklı beslenmenin öneminin farkındadırlar. Özellikle sütü, peyniri ve vitamin içeren besinleri tercih ederler.

- Dini inançları yok denecek kadar azdır. İbadetler ve dini ritüellerden hiç hoşlanmazlar. Ateizme meyillidirler.

- Giyilebilir cihazlarla çok ilgilidirler.

- Aşırı tüketim sevmezler. Ebeveynlerinin sahip oldukları kıyafetleri, eşyaları, mücevherleri vs. kullanmaktan hoşlanırlar.

- Daha çok X ve Y kuşağı ebeveynleri tarafından şımartılırlar.

- $X$ ve $Y$ kuşağı ebeveynlerinden çok etkilenirler.

- Erişim kabiliyetlerinden dolayı girişimci bir ruha sahiptirler.

- Sosyal medyaya çok inanırlar. Dünyayı sosyal medya aracıl1ğiyla tanirlar.

- Sosyal medya aracılığıyla iletim kursalar da yalnız olmayı her zaman tercih ederler. Kendi kendilerine yetebilirler.

- Online alış-veriş yapmayı tercih ederler.

- İnsanlarla iletişimde neredeyse hiç fiziksel temas kurmazlar.

- Büyük zorlukların üstesinden gelebilecek yüksek düzeyde becerilere sahiptirler.

- Zevk aldıkları şeyleri tekrarlarlar. Aynı filmi, aynı müziği defalarca deneyimleyebilirler.

- Aynı anda iki işi yapmazlar. 
- Çevresel ve sosyal sorunlarla ilgilenirler.

- An'1 yaşarlar. Geleceği veya geçmişi düşünmezler.

- Her şey hemen olsun isterler. Tez canlıdırlar.

Alfa kuşağının özelliklerini anlamak önemlidir çünkü geleceği temsil etmektedirler ve gelecek on yılı ve sonrasını anlamak için bizlere katkı sağlayacaklardır.

\section{Alfa Kuşağı ile İlgili Yapılan Çalışmalar}

Alfa kuşağı ile ilgili 2014-2020 yılları arasında yapılan çalışmalar incelenmiştir. Alfa kuşağını tanımaya ilişkin yapılan çalışmalar incelendiğinde Alfa kuşağına mensup bireylerin önceki kuşaklara kıyasla sınır tanımayan, düşüncelerini açılamaktan sakınmayan, geleneksel güç, yetki ve hiyerarşi yapılarını tanımayan bireyler oldukları sonucuna varılmıştır (Jha, 2020; McCrindle ve Fell, 2020; Barkowitz, 2016; Furia, 2015,). Dahası bu kuşağın diğer kuşaklara kıyasla daha meraklı, huysuz, hareketli, benmerkezci olma gibi davranışlar sergiledikleri tespit edilmiştir (Apaydın ve Kaya, 2017). Teknolojinin içine doğan Alfa kuşağının bir siber kültüre sahip oldukları dolayısı ile eğitimlerinin de görsel okur-yazarlık, karakter eğitimi gibi teknolojiye uygun yöntemler kullanılarak hazırlanması gerektiğinin üzerinde durulmaktadır (Ramadlani ve Wibisono, 2017). Eğitim konusundaki bir diğer öneri de özellikle Alfa kuşağının özellikle okul öncesi eğitiminde teknoloji desteğiyle oyunlaştırarak öğrenme yönteminin uygulanmasıdır (Tootell vd., 2014).

Alfa kuşağına yönelik pazarlama çalışmalarını belirlemek üzere yapılan araştırmada pazarlama çalışmalarından önce bu son kuşağın dikkatlice tanımlanması ve karakterize edilmesi gerektiği sonucuna varılmıştır (Nagy ve Kölcsey, 2017).

Çalışma hayatına yönelik çalışmalarda ise; Reis (2018) Alfa kuşağının örgütsel ortamdaki olası davranışlarını inceleyen çalışmasında Alfa kuşağının okul ve aile ortamlarındaki davranışlarını analiz ederek bu özelliklerin örgütsel ortamı nasıl etkileyebileceğine dair bir projeksiyon geliştirmeyi amaçlamıştır. Araştırma sonuçları bu kuşağın yaratıcılık, dinamizm, liderlik ve teknoloji ile güçlü bir bağlantıya odaklanan davranışsal özelliklere sahip bireylerden oluştuğunu göstermiştir. Dolayısı ile bu davra- 
nışsal özelliklerin karar verme özerkliğine, liderlik özelliklerine ve teknoloji ile ilgili olacak olan gelecekteki mesleki seçimleri ve kariyerlerinde son derece etkili olacağı düşünülmektedir. Kısaca Alfalar geleceğe yön verecek bir kuşak olduklarından bu kuşağın çalışma hayatına uyumlaştırılması (Viegas, 2015), çalışma hayatının da Alfa kuşağına hazırlanması gerekmektedir (Schawbel, 2014).

\section{Çalışma Hayatında Alfa Kuşağı}

McCrindle ve Fell'ın (2020, s.3) öngörüsüne göre Alfa kuşağ 2025 yılında 2 milyarlık bir popülasyonla dünya tarihinin en büyük kuşak nüfusuna sahip olacaktır. Günümüzde dünya genelinde haftada ortalama 2,5 milyon Alfa doğmaktadır. Bu da yılda 130 milyon Alfa'nın doğması anlamına gelmektedir (Lamble, 2018). Birleşmiş Milletler verileri ışı̆̆ında (www.un.org.) ABD'de 2050 yılında en yaşlısı 40 yaşında olacak olan Alfa nüfusunun 35 milyona ulaşacağ 1 düşünülmektedir. Diğer yandan Çin'in 2015 yılında 35 yıl aradan sonra "tek çocuk zorunluluğu" politikasına son vermesi hesaba katıldığında Alfa kuşağının nüfus yoğunluğunun Çin ve Hindistan başta olmak üzere Afrika kıtasında yer alan gelişmekte olan ülkelerde olacağı tahmin edilmektedir (Kaynak, 2017). Bu durum Türkiye'de de farklılık göstermemektedir. Türkiye İstatistik Kurumu'nun (TÜIK) Adrese Dayalı Nüfus Kayıt Sistemi (ADNKS) 2017 verilerine göre Alfa kuşağ 2040 yılında ülkemizde 26 milyona ulaşarak ülke nüfusunun \%26'sını oluşturacağı öngörülmektedir (Apaydın ve Kaya, 2020, s.126).

Alfa kuşağına mensup bireyler onlarda var olan sorun çözme, yaratıcılık karar verme, eleştirel düşünme, esneklik, özyönetim becerisi gerektirecek sosyal, çevresel ve ekonomik birçok sorunla gelecekte karşılaşacaklardır. Alfalar bu becerilerle gelecekte toplumun temelini oluşturacak ve topluma en büyük desteği vereceklerdir (Furia, 2015, s.3).

Çalışma hayatı hazır olsun ya da olmasın 10 yıl sonra en yaşlı Alfa 21 yaşında olacak ve Alfalar çalışma hayatına artık yavaş yavaş girmiş bulunacaktır. Örgütler gelecekte var olmak aynı zamanda gelişmek istiyorlarsa Alfa kuşağının şekillendireceği geleceği anlamak zorundadırlar (Brown, 2000, s.12). Teknolojik gelişmelerin Alfa çocukları üzerindeki etkileri tespit edilerek bu kuşağın çalışma hayatına uyumlaştırılmaları giderek gerekli bir hale gelmektedir (Viegas, 2015, s.27). Bu kuşağın özellikle 
teknoloji becerisi göz önüne alındığında aslında örgütlerin teknolojik dönüşümlerini Alfalara uyum sağlayacak şekilde yapmaları gerekebilir.

Alfa kuşağının çalışma hayatına girmelerine çok az süre kalmışken özellikle pazarlamacılar ve insan kaynakları uzmanları hala bu kuşağı görmezden gelmektedir. Schawbel (2014) ile Ramadlani ve Wibisono (2017) yapmış oldukları çalışmalarda Alfa kuşağının özelliklerinden yola çıkarak Alfalarla ilgili çalışma hayatında karşımıza çıkabilecek bazı tahminlerde bulunmuşlardır. Bu tahminler;

- Alfa kuşağ 1 diğer kuşaklara kıyasla daha girişimci bir ruha sahip olacaklardır. Aslında bu kuşaktan sonraki her kuşak bir öncekinden daha girişimci olacaklardır. Çünkü çok erken yaşlarda bilgiye ve gücün kaynağına erişim imkânına sahip olacaklardır. Hatta yakın zamanda 10 yaşını tamamlamış kendi işlerinin sahibi Alfaları görmemiz mümkün olacaktır.

- Sosyal ağlar olmadan hiçbir işlerini halletmeyeceklerdir. Eğer bir işletme Alfalara pazarlama veya işe alma perspektifinden ulaşmak istiyorsa mutlaka o işletmenin mobil uyumlu bir web sitesinin olması gerekecektir. Dahası sosyal iletişimin kendi ihtiyaçlarına göre özelleşmesini bekleyeceklerdir.

- Özellikle çevirim içi alış veriş yapacaklar ve önceki kuşaklara göre daha az yüz yüze insan ilişkisine sahip olacaklardır. Bağlantıları çok olmasına rağmen meslektaşlarıyla bile yüz yüze konuşmak için çok az zaman harcayacaklardır.

- $\quad$ X ve Y kuşağı ebeveynleri tarafından şımartılan Alfa kuşağı aynı zamanda onların fikirlerinden çok etkileneceklerdir. Bu sebeple işletmeler Alfa kuşağını hedef alan reklam ve satış çalışmalarında onların ebeveynlerini göz önüne almaları gerekecektir.

- Kendi kendilerine yetebilen, daha iyi eğitimli ve büyük zorluklara hazırlıklı bireyler olacaklardır. Alfa kuşağı küresel ısınma ve kıtlık dâhil dünyanın en büyük zorluklarının çoğunun üstesinden gelmek zorunda kalacaklardır. Emeklilik ve sağlık gibi sosyal güvenceleri veya sosyal güvenlik ağları olmayacaktır.

- Alfa nüfusu gelişmemiş ya da gelişmekte olan ülkelerde yoğunlaşacağı, refah seviyesi yüksek olan ülkelerde ise seyrekleşeceği için gelir adaletsizliği başka bir ifadeyle zengin ve fakir arasındaki uçurum daha da belirgin bir hale gelecektir. 


\section{Sonuç ve Öneriler}

Önceki yıllara kıyasla günümüzde daha fazla kuşak bir arada yaşamaktadır. Kuşaklar sadece aile içinde değil okullarda ve örgütlerde tüm düzeyleri kapsayan bir etkileşimde bulunmak zorundadırlar (McCrindle ve Wolfinger, 2010). Almedia ve Silva (2011)'e göre kuşaklar aile ortamında, akran grubunda, sosyal bağlamda, iş ve eğitim ortamlarında sürekli etkileşimde bulundukları bir sosyal ağ içerisindedirler. Günümüzde bu sosyal ağ içerisinde sessiz kuşak, bebek patlaması kuşağı (Baby boomers: BB), X, Y, Z kuşakları ve Alfa kuşağı olmak üzere altı tane kuşak yer almaktadir (Howe ve Strauss, 2005; Lanchester ve Stillman, 2002; Martin ve Tulgan, 2003). Kuşakların en belirgin özelliklerine bakıldığında sessiz kuşak aile kavramına çok önem veren, otoriteye saygıll, dürüst ve ahlaklı bir kuşaktır. BB kuşağı disiplinli, çalışkan ve iş birliğine açık kişilerdir. X kuşağ 1 çalışan ebeveynler sebebiyle yalnız büyümüş, erken yaşlarda kendi bakımlarını üstlenmiş bir kuşak olduklarından yalnız çalışmayı tercih eden ve otoriteden hoşlanmayan bireylerdir. Y kuşağ teknoloji ile tanışmış ilk kuşaktır. Özgürlüklerine düşkün girişimci ruhlulardır. Z kuşağı 21.yüzyıla ait ilk kuşaktır. Dijital teknoloji ile tanışmışlardır. Sosyal medya ve akıllı cihazlar ilk kez bu kuşak döneminde ortaya çıkmıştır. Bu noktadan hareketle özellikle çalışma hayatında yer alan dört kuşağın (BB, X, Y, Z kuşakları) özelliklerine ilişkin bilgilerden insan kaynakları uzmanlarının ve üst düzey yöneticilerin bu çalışmadan faydalanacağ 1 düşünülmektedir.

'Dijital Yerliler' olarak da tanımlanan Alfa kuşağı mensupları yaşamlarının ilk yıllarından itibaren teknolojinin günlük yaşamlarının ayrılmaz bir parçası olan, yaşam biçimlerini ve davranışlarını etkileyen dijital dünya ile artık bir bütün olmuşlardır. Alfa kuşağı girişimci ruhlu, yaratıcl, dinamik, kural tanımayan, bağımsızlıklarına düşkün ve teknoloji bağımlısı gibi karakteristik özelliklere sahiptir. Bu kuşağın temsilcilerinin büyük ölçüde teknolojiyle ilişkili meslekleri tercih edecekleri, lider odaklı davranışlar sergileyecekleri, yüz yüze iletişimden hoşlanmadıkları için gerek kişisel gerekse işle ilgili bütün gereksinimlerini dijital dünyadan karşılayacakları düşünülmektedir. Youtuber, blog yazarlığı, influencer gibi yeni meslekler Alfalar arasında daha şimdiden oldukça popüler olmuştur. Hatta bazı Alfalar bu mecralardan ciddi gelir elde etmektedir. 
Diğer yandan henüz çalışma hayatına girmemiş olan bu kuşağın gelecekte çalışma hayatında başarılı olabilmesi için doğru eğitimi alması gerekmektedir. Alfa'ların yaşadıkları dönemdeki teknolojik gelişmeler ve Alfa'ların karakteristik özellikleri göz önüne alındığında, 2021 yılı itibari ile tamamı öğrenci olan ve henüz çalışma hayatına girmemiş olan Alfa'ların çağlarına uyum sağlayabilmeleri için eğitim sisteminin temelden değişmesi gerekmektedir (Bennett vd., 2008, s.776). Araştırmacılar Alfa kuşağının sahip olduğu özellikler nedeniyle geleneksel eğitim yöntemlerinin bu yeni öğrenci grubunun entelektüel, sosyal ve duygusal ihtiyaçlarını karşılayacak donanıma sahip olmadığını düşünmektedir (Bennnett vd., 2008; Oblinger ve Oblinger, 2005; Prensky, 2001). Özellikle teknolojik bilgiden yoksun öğretmenlerin Alfa kuşağı ile ciddi sorunlar yaşayacağı düşünülmektedir (Tapscott, 2009, s.131). Alfa kuşağ1 yüksek hızda öğrenmeye, rastgele web bağlantıları kurmaya, görsel ve dinamik bilgileri işlemeye alışkın oldukları için daha çok çevirim içi oyun tabanlı öğrenme onlar için uygun olacaktır (Brown, 2000, s.12).

Alfa kuşağı ile ilgili yapılan az sayıdaki çalışmada ebeveynlerin ve öğretmenlerin bu kuşak hakkında bilgi eksikliğini ortaya koymuştur (Jha, 2020; Reis, 2018). İlgili yazında Alfa kuşağını tanıtıcı daha fazla çalışmaya ihtiyaç duyulmaktadır. Bu konuyla ilgili materyal ve bibliyografik kaynak bulmanın zorluğu araştırma amacının doğru seçildiğini ve temanın araştırmaya değer olduğunu göstermektedir. Alfaların gelişimleri takip edildikçe gelecekte çalışma hayatındaki etkileri konusunda daha fazla bilgi sahibi olunacağı düşünülmektedir.

Gelecek araştırmalar için kurallardan ve otoriteden hoşlanmayan Alfa kuşağı ve otorite sorusu gündeme gelebilir. İleride bu kuşağın üyelerinin hiyerarşik olarak yapılandırılmış organizasyon ortamında yöneticileri ile iletişimlerinde nasıl davranış sergileyeceklerinin araştırılması önerilebilir. 


\title{
EXTENDED ABSTRACT
}

\section{Human Resource of the Future in Working Life: The Alpha Generation}

\author{
Zümrüt Hatun Demirel \\ Yildırım Beyazit University
}

With the raising of the retirement age due to the policies of the states, human resources in any organization now consist of different generations. The generation factor of the employees affects their work commitment, career development and teamwork (Pathirage and We-erasinghe, 2020, s.2). Individuals from different age groups have different experiences, different views, different habits and different working styles (Yiğit and Aksay, 2015, p.105). Therefore, different work-related behaviors can be detected between generations, and these different behaviors affect the productivity of an organization and cause many conflicts directly and indirectly (McGuire, Todnem and Hutchings, 2007, s. 593). Today, managing a multi-generational workforce is becoming more and more difficult, mainly due to the different work-related behaviors of generations.

Generation is a concept that refers to a group of individuals who have similar birth years and experiences, whose thoughts, attitudes, values, beliefs and behaviors are affected by various factors and which in turn influences these factors (Kupperschmidt, 2000, p.67). In terms of demographics, generation represents a picture of nations in their birth years (McCrindle, 2014, p.35). In general, generation is categorized by age. As an indicator of generation, age is a way of facilitating understanding of the complex society (Rogler, 2002, p.1015).

When the literature on the concept of generation is examined, six different generations are mentioned (Howe and Strauss, 2005; Lanchester and Stillman, 2002; Martin and Tulgan, 2003). These generations are: Silent Generation, Baby Boomer Generation, Generation X, Generation Y, Generation $Z$ and Alpha generation (Cook, 2015; Hammill, 2005; Wasserman, 2007). Today, the baby boom generation and $X, Y, Z$ generations are active in business life. 
The Silent Generation: The silent generation is the oldest generation of our age, they were born between 1925-1945 and most of them are retired. The silent belt is also known as the traditional belt. (Strauss and Howe, 1991, p.198). They have been the founders of the infrastructure, economy, institutions and organizations of this generation's societies. They played an important role in the transition from an agricultural economy to a modern, industrialized economy (Stevenson, 2009, p.55). The basic values of this generation, which was highly affected by the war period, are respect for authority, business ethics and honesty (Kyles, 2005, p.54). These individuals are extremely loyal to the organizations they work for.

Baby Boomers: The generation born between 1946 and 1964 is known as the baby boom generation. It is the second generation according to the generation classification (Holton and Fraser, 2015, p.3). The members of this generation are disciplined in working life, believing that the price such as "sacrifice" must be paid in order to be successful, hardworking, loving cooperation, valuing their careers, loyal to their employers and working in the same workplace for a long time. Moreover, these people are seen as workaholics who make sense of their lives with their jobs (Tolbiz, 2018, p.24). The BB generation is a generation that is sensitive to the environment and social events, believes in the equality of men and women and fights against racial discrimination. This generation formed the basis of the rebellion movement called "68 Movement" in their youth (Crampton and Hodge, 2006, p.20).

Generation X: Generation X, which is the third generation classification, includes people born between 1965 and 1980 (Altuntuğ, 2012; Kaifi, Nafei, Khanfar, and Kaifi, 2012). Generation X is the generation with the lowest number of population in the classification of generations (Keengwe and Agamba, 2014, p.274). Especially women started to participate in working life predominantly in this period. Therefore, this generation is the first generation where both parents mostly work outside the home and have to look after themselves for hours every day while the parents are at work (Strauss and Howe, 1991, p.200).

Generation Y: Generation Y, which comes after the $X$ generation and is the fourth generation classification, consists of individuals born between 1981-1999 (Harber, 2011; Rainness, 2003). It is the generation with the highest population after the baby boom generation (Kavalc1 and Ünal, 
2016, p.1037). One of the most important characteristics of the $Y$ generation is that they are individual, self-indulgent and entrepreneurial. Some of them are bosses of their own business and have high living standards (Holton and Fraser, 2015, p.5).

Generation Z: Generation Z is the first generation born in the 21st century and is the fifth generation of the generation classification. According to some sources, those born between 2000-2020 (Levickaite, 2010; Malloy, 2012); According to some sources, those born between 1995-2010 (Bejtkovsky, 2016; Pathirage and Weerasighe, 2020) are included in the $Z$ generation. The most important point that distinguishes Generation $Z$ from other generations is that they were born and grew up with digital technology (Beyaz, 2020, p.56). Generation Z can work in both the real and virtual world. They can make a fast and continuous journey between these two worlds (Mistik, 2019, p.78). They can easily access a data they need and share that data. They have a high capacity to access information. They do not only consume information, but also have the ability to produce and control it (Taş, et al., 2017, p.1036).

Alpha Generation: The Alpha generation, the last representatives of humanity in the world, includes those born in 2010 and after. According to some researchers, those born between 2010 and 2025 were included in the Alpha generation (Apaydın and Kaya, 2020; Jha, 2020; McCrindle, 2007). Alpha generation is also called "digital natives". They have advanced knowledge and skills related to information technologies. They know very well the mother tongue of computers, video games and the internet, namely the digital world, and they use this language within themselves (Prensky, 2001, p.1) The most important thing that can be said about the alpha generation is the digital environment in which they were born. Technology, parents, educators and social interactions are the most important elements that affect their daily lives (Tootell, Freeman and Freeman, 2014, p.82). Alpha generation individuals will face many social, environmental and economic problems in the future that will require problem solving, creativity, decision making, critical thinking, flexibility and self-management skills. With these skills, alphas will form the basis of the society in the future and will give the greatest support to the society (Furia, 2015, p.3). Alpha generation has characteristic features such as en- 
trepreneurial spirit, creative, dynamic, unruly, independent and technology addicted. It is thought that the representatives of this generation will prefer professions related to technology to a large extent, exhibit leaderoriented behaviors, and because they do not like face-to-face communication, they will meet all their personal and business needs from the digital world.

In this study, first of all, it is aimed to explain the general and characteristic features of the current generations in working life and their behaviors in working life, to define the Alpha generation, which will be the human resource of the future, and to explain its characteristic features and expected behaviors in business life.

\section{Kaynakça / References}

Adıgüzel, O. Batur, H. ve Ekşili, N. (2014). Kuşakların değişen yüzü ve y kuşağı ile ortaya çıkan yeni çalışma tarzı: Mobil yakalılar. Süleyman Demirel Üniversitesi Sosyal Bilimler Enstitüsü Dergisi, 1(19), 165-182.

Almeida, F.H and Silva, M. (2011). L.L.Influence of parents in the process of professional choice of children: A review of the literature. Psico-USF, 16(1),75-85.

Altuntuğ, N. (2012). Kuşaktan kuşağa tüketim olgusu ve geleceğin tüketici profili. Organizasyon ve Yönetim Bilimleri Dergisi, 4(1), 203-212.

Alwin, D.F. (2002). Generations X, Y And Z: Are they changing America. American Sociological Association Contexts, 42(1), 42-51.

Altunbay, M. ve Bıçak, N. (2018). Türkçe Eğitimi derslerinde "Z Kuşağı" bireylerine uygun teknoloji tabanlı uygulamaların kullanımı. Zeitschrift für die Welt der Türken/Journal of World of Turks, 10(1), 127-142.

Andrea, B., Gabriella, H. C. and Timea, J. (2016). Y and Z generations at workplaces. Journal of Competitiveness, 8(3), 90-106.

Apaydın, Ç. ve Kaya, F. (2020). An analysis of the preschool teachers' views on alpha generation. European Journal of Education Studies, 6(11), 123140. doi: 10.5281/zenodo.3627158.

Arslan, A. ve Staub, S. (2015). Kuşak Teorisi ve iç girişimcilik üzerine bir araştırma. KAÜ İ̈BF Dergisi, 6(11), 1-24.

Ayhün, S.E. (2013). Kuşaklar arasındaki farklılıklar ve örgütsel yansımaları. Ekonomi ve Yönetim Araştırmaları Dergisi, 2(1), 93-109. 
Baker, A. (2018). The hemingway project. Hemingway, the fitzgeralds, and the lost generation: An interview with kirk curnutt. http://www.thehemingwayproject.com/2018/08/14/hemingway-the-fitzgeralds-andthe-lost-generation-an-interview-with-kirk-curnutt-3/ adresinden 15.02.2021 tarihinde erişilmiştir.

Barkowitz, D. (2016, 28 Ocak). 13 things to know about the Alpha Generation the newest generation has no purchasing power yet, but will soon take over the world. https://adage.com/article/digitalnext/13-things-alpha-generation/302366 adresinden 01.03.2021 tarihinde erişilmiştir.

Bennett, S., Maton, K. and Kervin, L. (2008). The 'digital natives' debate: A critical review of the evidence. British Journal of Educational Technology, 39(5), 775-786.

Bejtkovský J. (2016). The employees of baby boomers generation, generation $X$, Generation $Y$ and Generation $Z$ in selected Czech corporations as conceivers of development and competitiveness in their corporation. Journal of Competitiveness, 8(4), 105-123.

Beyaz, R. (2020). Z kuşağı tüketicilerin kişilik özellikleri ve bilinçli tüketim eğilimleri arasındaki ilişkinin incelenmesi. Gençlik Araştırmaları Dergisi, 8(22), 51-69.

Bilgin, D. C. (2010, Ocak 18). Evet efendimci' yalakalar CEO'ları kriz körü yaptı. 'Evet efendimci' yalakalar CEO'ları kriz körü yaptı - Sondakika Ekonomi Haberleri (hurriyet.com.tr) adresinden 03.02.2021 tarihinde erişildi.

Brown, J. S. (2000). Growing up digital: How the Web changes work, education, and the ways people learn. Change, 32(2),10-20.

Buckley, M. R., Beu, D. S., Novicevic, M. M. and Sigerstad, T. D. (2001). Managing generation next: Individual and organizational perspectives. Review of Business, 22(1/2), 81-86.

Cennamo, L. (2005). Generational differences in work values, work-related outcomes and person-organisation values fit. Master Thesis. Massey University, New Zelland.

Chen, H. (2010) Advertısing and Generational Identity: A Theoretıcal Model. American Academy of Advertising. Conference. Proceedings (Online); Lubbock: 132-140. Lubbock: American Academy of Advertising.

Cook, V. S. (2015). Engaging generation Z students. 02.02.2021 tarihinde https://sites.google.com/a/uis.edu/colrs cook/home/engaging-generation-z-students. adresinden erişildi. 
Crampton, S. and Hodge, J. (2006). The supervisor and generational differences. Organizational Culture, Communications and Conflict, 11, 19-22.

Çelik, E. A. ve Çelik, S. (2016) Generations and their relations in social processes. SSPS, 1(1), 117-127.

Çetin, C. ve Karalar, S. (2016). X, Y ve Z Kuşağı öğrencilerin çok yönlü ve s1nırsız kariyer algıları üzerine bir araştırma. Yönetim Bilimleri Dergisi, $14(28), 157-197$.

Düren, Z. (2000). 2000'li yıllarda yönetim. (1. Basım). İstanbul: Alfa Basım Yayın Dağıtım.

Erdoğdu, E. (2013). Insan kaynakları yönetiminde personel seçimi ve psikoteknik testlerin önemi. Yüksek Lisans Tezi. Atılım Üniversitesi, Sosyal Bilimler Enstitüsü, İşletme Yönetimi Anabilim Dalı, Ankara.

Eyerman, R. and Turner, B. (1998). Outline of a theory of generations. European Journal of Social Theory, l(1), 91-106.

Furia, F. (2015). Interview: Fernanda Furia and the importance of technology in education. Pedagogical Practices: Registers and Reflections, 3(1), 1-8.

Greenfield, (2009). Technology and informal education: What is taught, what is learned. Science, 323(5910), 69-71.

Giancola, F. (2006). The generation Gap: More myth than reality?. Human Resource Planning, 29(4), 32-7.

Guillot-Soulez, C. and Soulez, S. (2014). On the heterogeneity of Generation Y job preferences. Employee Relations, 36(4), 319-332.

Hammill, G. (2005). Mixing and managing four generations of employees. Fairleigh Dickinson University - FDU Magazine, 03.02.2021 tarihinde http://www.fdu.edu/newspubs/magazine/05ws/generations.htm adresinden erişildi.

Hansen, J. and Leuty, M. (2012). Work values across generations. Journal of Career Assessment, 20(1), 34-52.

Harber, J. G. (2011). Generations in the workplace: Similarities and differences. Electronic Theses and Dissertations Paper 1255. https://dc.etsu.edu/etd/1255 adresinden 03.03.2021 tarihinde erişilmiştir.

Hariadi, B., Dewiyani, M. J. and Pantjawati S. (2016). Development of webbased learning application for generation Z. International Journal of Evaluation and Research in Education (IJERE), 5(1),60-68. 
Holton, T. and Fraser, B. (2015). Generation Z and technology: Constructing tomorrow's boundary spanners. Defence Research and Development Canada Scientific Report DRDC-RDDC-2015-R167.

Howe, N. and Strauss, W. (2005). The next 20 years: How Customer and workforce attitudes will evolve. Harvard Bunsiness Review, 85(7-8), 4152.

Jha, A. K. (2020). Understanding generation alpha. https://doi.org/10.31219/osf.io/d2e8g. adresinden 03.02.2021 tarihinde erişildi.

Johnson, M., and Johnson, L. (2010). Generations, Inc.: From boomers to linksters-managing the friction between generations at work. New York: Amacom Div American Mgmt Assn.

Jorgensen, B. (2003). Baby boomers, generation $X$ and generation $Y$ ? Policy implications for defence forces in the modern era. Foresight, 5(4), 4149.

Kaifi, B. A., Nafei, W., Khanfar N. M. and Kaifi, M. M. (2012). A multi-generational workforce: Managing and understanding millennials. International Journal of Business and Management, 7(24), 88-93.

Karp, H., Fuller, C. and Sirias, D. (2002). Bridging the boomer Xer gap. Creating authentic teams for high performance at work. Palo Alto: Davies Black Publishing.

Kavalcı, K. ve Ünal, S. (2016). Y ve Z kuşaklarının öğrenme stilleri ve tüketici karar verme tarzları açısından karşılaştırılması. Atatürk Üniversitesi Sosyal Bilimler Enstitüsü Dergisi, 20(3), 1033-1050.

Kaynak, A. (2017). X, Y, Z yetmez; Biraz da alfa olsun. http://www.mediacatonline.com/x-y-z-yetmez-biraz-da-alfa-olsun/ adresinden 02.03.2021 tarihinde erişilmiştir.

Keengwe, J. and Agamba, J. J. (2014). Models for improving and optimizing online and blended learning in higher education. Eds. Lee, T. and D. H. Lim, Learning through Web-Based Authoring Tools. Hershey: IGI Global.

Kertzer, D. (1983). Generation as a sociological problem. Annual Review of Sociology, 9, 125-149.

Kırık, A. M. ve Köyüstü, S. (2018). Z Kuşağı konusunda yapılmış tezlerin içerik analizi yöntemiyle incelenmesi. Gümüşhane Üniversitesi İletişim Fakültesi Elektronik Dergisi, 6(2), 1497-1518.

Kupperschmidt, B. R. (2000). Multigeneration employees: Strategies for effective management. The Health Care Manager, 19(1), 65-76. 
Kuyucu, M. (2014). Y Kuşağı ve Facebook: Y Kuşağının Facebook kullanım alışkanlıkları üzerine bir inceleme. Elektronik Sosyal Bilimler Dergisi, 13(49), 55-83.

Kyles, D. (2005). Managing your multigenerational workforce. Strategic Finance, December, 53-55.

Lamble, L. (2018, 23 Nisan). With 250 babies born each minute, how many people can the Earth sustain? The Guardian. https://www.theguardian.com/global-development/2018/apr/23/population-how-manypeople-can-the-earth-sustain-lucy-lamble adresinden 03.02.2021 tarihinde erişildi.

Lancaster, L. C. and Stillman, D. (2002). When generations collide: Who they are. Why they clash. How to solve the generational puzzle at work. New York, NY: Harper Collins.

Latif, H. ve Serbest, S. (2014). Türkiye' de 2000 kuşağı ve 2000 kuşağının iş ve çalışma anlayışı. Gençlik Araştırmaları Dergisi, 2(4), 133-163.

Levickaite, R. (2010). Generations X Y Z: How social networks form the concept of the world without borders the case of lithuania. LIMES, 3(2), 170-183.

Losyk, B. (1997). Generation X: What they think and what they plan to do. The Futurist, 31, 39-44.

Lower, J. (2008). Brace yourself here comes generation Y. Critical Care Nurse, 28(5), 80-85.

Malloy, E. (2012). Gen Y, and on to Z. The Foreign Service Journal, October, 2841.

Martin, C. A. and Tulgan, B. (2003). Managing the generation mix-from collision to colobration. Proceedings of The Environment Federation, 12, 975983.

McCrindle M. (2007) Bridging the Gap: An Employers Guide to Managing and Retaining the New Generation of Apprentices and Trainees. McCrindle Research, Sydney.

McCrindle, M. and Wolfinger, E. (2010). Generations defined. Ethos, 18(1), 813.

McCrindle, M. (2014) The ABC of XYZ: Understanding the Global Generations. Australia: McPherson's Printing Group.

McCrindle, M. and Fell, A. F. (2020) Understanding Generation Alpha. https://mccrindle.com.au/insights/blog/gen-alpha-defined/. adresinden 02.03.2021 tarihinde erişilmiştir. 
McGuire, D., Todnem, R. and Hutchings, K. (2007). Towards a model of human resource solutions for achieving intergenerational interactions in organizations. Journal of European Industrial Training, 31(8), 592-608.

Mıstık, A. (2019). Okul öncesi eğitim yapılarında öğrenme mekânları ve kullanıcı olarak Alfa Kuşağı. Yüksek Lisans Tezi. Eskişehir Anadolu Üniversitesi Güzel Sanatlar Enstitüsü, Eskişehir

Mort, F. (1996). Cultures of consumption. Masculanities and social spaces in late 20th Century Britain. London: Routledge.

Nagy, A. and Kölcsey, A. (2017). Generation alpha: Marketing or science?. Acta Technologica Dubnicae, 7(1), 107-115.

Oblinger, D. (2003). Boomers and Gen-X'ers Millennials, understanding new students. Educause Review, 38(4), 37-47.

Oblinger, D. and Oblinger, J. (2005). Is it age or IT: First steps towards understanding the net generation. In D. Oblinger and J. Oblinger (Eds), Educating the Net generation (p.2.1-2.20). Boulder, CO: EDUCAUSE. http://www.educause.edu/educatingthenetgenadresinden 03.02.2021 tarihinde erişildi.

Pathirage U. K. and Weerasinghe T. D. (2020). Difference of work related behaviors between Generation X and Generation Y: A study of professionals of a development bank in Sri Lanka. Kelaniya Journal of Management, 9(1), 1-15.

Prensky, M. (2001). Digital natives, digital immigrants. On The Horizon, 9(5), $1-6$.

Quinn, P. (2010). A multigenerational perspective on employee communications. Risk management, 57(1), 32-34.

Raines, C. (2003). Connecting generations: The sourcebook for a new workplace. Berkeley, CA: Crisp Publications.

Ramadlani, A. K. and Wibisono, M. (2017). Visual literacy and character education for alpha generation. http://sastra.um.ac.id/wp-content/uploads/2017/11/01-07-Abdul-Khaliq-Ramadlani-Marko-Wibisono LAYOUTED.pdf. Adresinden 21.12.2020 tarihinde erişilmiştir.

Reeves T. C. and Oh E. (2008). Generational differences, in handbook of research on educational communications and technology. 3th ed., New York: Taylor\&Francis Group.

Reis, T. A. (2018). Study on The Alpha Generation And The reflections of its behavior in the organizational environment. Quest Journals Journal of Research in Humanities and Social Science, 6(1), 09-19. 
Reisenwitz, T. H. and Iyer, R. (2009). Differences in Generation X and Generation Y: Implications for the organization and marketers. The Marketing Management Journal, 19(2), 91-103.

Riedling, M. A. (2007) An educator's guide to information literacy: What every high school senior needs to know. Book News, Inc., Portland, United States, Portland.

Rogler, L. H. (2002). Historical generations and psychology: The case of the Great Depression and World War II. American Psychologist, 57(12), 1013-1023.

Schawbel, D. (2014). 5 predictions for Generation Alpha. www.danschawbel.com. Adresinden 21.12.2020 tarihinde erişilmiştir.

Scheef, D. and Theifoldt, D. (2004). Gen X and the Milennials what we need to know about mentoring the new generations. The Learning Cafe, 5-7.

Segrin, C., Woszidlo, A., Givertz, M., Dauer, A. and Murphy, M. T. (2012). The association between overparenting, parent-child communication, and entitlement and adaptive traits in adult children. Family Relations, 61, 237-252.

Serinikli, N. (2019). Transformation of human resources in digitalization: $Y, Z$ and Alpha Generatıons. C. Akar ve H. Kapucu (Der.) Contemporary Challenges In Busıness and Life Sciences içinde 181-187, London: IJOPEC Publication Limited.

Seyyar, A. ve Öz, C. S. (2007). İnsan kaynakları terimleri ansiklopedik sözlük. Sakarya: Değişim Yayınları.

Stevenson, A. (2009) .Chapter 3: The generation map. The ABC of XYZ understanding the global generations. Ed. Mark McCrindle. 35-72. Australia: McPherson's Printing Group.

Strauss, W. and Howe, N. (1991). Generations: The history of America's future, 1584 to 2069. New York, NY: Quill William Morrow.

Yigit, S. ve Aksay, K. (2015). A Comparison between Generation X and Generation $\mathrm{Y}$ in terms of individual innovativeness behavior: The case of Turkish health professionals. International Journal of Business Administration, 6(2), 65-73.

Tahmaz, E. (2019). Teknoloji şirketlerinde $Y$ ve Z Kuşağı çalışanlar için geliştirilen insan kaynakları uygulamaları. İstanbul: Irdıtech 2019 Uluslararası ARGE, İnovasyon ve Teknoloji Yönetimi Kongresi Bildiriler Kitabı (3 May1s 2019). 
Tapscott, D. (2009). Grown up digital: How the net generation is changing your world. United States: McGraw-Hill.

Taş, H. Y., Demirdöğmez, M. ve Kü̈çükoğlu, M. (2017). Geleceğimiz Olan Z Kuşağının çalışma hayatına muhtemel etkileri. OPUS () Uluslararası Toplum Araştırmaları Dergisi-International Journal of Society Researches. 7(13). 1031-1048.

Ting, H., Lim, T. Y., Cyril de Run, E,Koh, H. and Sahdan, M. (2018). Are we baby boomers, Gen X and Gen Y? A qualitative inquiry into generation cohorts in Malaysia. Kasetsart Journal of Social Sciences, 39(2018) 109-115.

Toch, T. and Frady, M. (1984, 19 Eylül). The making of 'to save our schools, to save our children': A conversation with Marshall Frady. Bethesda, ABD: Education Week. https://www.edweek.org/ew/articles/1984/09/19/05550017.h04.html. adresinden 15.02.2021 tarihinde erişildi.

Tolbiz, A. (2018). Generational differences in the workplace. Journal of Managerial Psychology, 23(8), 23-46.

Tootell, H., Freeman, M. and Freeman, A. (2014). Generation alpha at the intersection of technology, play and motivation. In R. H. Sprague Jr (Eds.). 47th Hawaii International Conference on System Sciences (HICSS), (82-90).

Turan, S. N. (2008). Resort Otellerde Stratejik Insan Kaynakları Yönetimi Sürecinde Performans Değerlendirmesinin Kariyer Yönetimine Etkileri ve Antalya İli Uygulaması. Yüksek Lisans Tezi, Gazi Üniversitesi, Eğitim Bilimleri Enstitüsü, Turizm İşletmeciliği Anabilim Dalı, Ankara.

Viegas, R. O. D. M. C. (2015). Alpha generation: A case study at the nursery education center of UFRN. Bachelor's thesis, Federal University of Rio Grande do Norte, Natal.

Wasserman, I. (2007). Generations working together. 02.02.2021 tarihinde https://www.entrepreneur.com/article/183720. adresinden erişildi.

Wiedmer, T. (2016). Generations do differ: Best practices in leading traditionalists, boomers, and Generations X, Y, and Z. The delta kappa gamma bulletin: International Journal for Professional Educators, 82(1), 51-58.

Williams , K. C., and Page, R. A. (2011). Marketing to the generations. Journal of Behavioral Studies in Business, 3(1), 1-17.

Yüksekbilgili, Z. (2015). Türkiye'de Y Kuşağının yaş aralığı. Elektronik Sosyal Bilimler Dergisi, 14(53), 259-267. 
Zemke, R., Raines, C. and Filipczak, B. (2013). Generations at work: managing the clash of boomers, gen Xers, and gen Yers in the workplace. New York: AMACOM Div American Mgmt Assn.

https://www.nufusu.com/turkiye-nufusu-yas-gruplari adresinden 20.02.2021 tarihinde erişildi.

https://www.pcmag.com/feature/371755/the-most-iconic-tech-innovationsof-the-2010s;

https://sozluk.gov.tr/ adresinden 16.01.2021 tarihinde erişildi.

https://time.com/collection/best-inventions-2018/

https://ime.com/collection/best-inventions-2019/

https:/turkey.unfpa.org/sites/default/files/pub-pdf/unfpa swop report 2020 english.pdf adresinden 10.01.2021 tarihinde erişildi.

https://www.un.org/development/desa/pd/

\section{Kaynakça Bilgisi / Citation Information}

Demirel, Z. H. (2021). Çalışma Hayatında Geleceğin İnsan Kaynağı: Alfa Kuşağı. OPUS-Uluslararası Toplum Araştırmaları Dergisi, 18(Yönetim ve Organizasyon Özel Say1s1), 1796-1827. DOI: 10.26466/opus. 895924. 